\title{
Igaz és hamis az új médiában
}

DOI : $10.46522 / \mathrm{S} .2021 .02 .08$

\author{
KÁLLAI R. Gábor PhD \\ Milton Friedman University, Budapest \\ kallai.r.gabor@gmail.com
}

\begin{abstract}
True and False in New Media
New media has become a part of everyday life. This is particularly true of Facebook, which everyone tends to visit, even if they deny it. Significant academics and seemingly serious politicians are as present on social media as charlatans and rogues; organizations with an interest in causing confusion are also active, while organizations dedicated to obstructing confusion are not passive. It is also well known that one wrong Facebook post can cause an avalanche - whether consciously or accidentally. On the net - and to a degree on Facebook - all facts appear directly or referenced as in line with reality and thus true. At the same time, all positions that are false are also present. It is common knowledge that false, faked, misleading, or - let's be honest - simply stupid statements are difficult to recognize, especially in the time of a pandemic. We face several entirely new phenomena which lack explanations based on scientific consensus. Social responses to the pandemic and the effects of political and bureaucratic efforts are controversial. Furthermore, even the best-intended actions - which in some cases are rational - cause interruptions in the usual carrying on of life, and factual pandemic news cause uncertainty. That is to say, true statements awaken the desire for "fake news". Wittgenstein closed his famous logical-philosophical essay with the words "that whereof we cannot speak, thereof we must remain silent". It is possible that the situation is now reversed. That whereof we must remain silent, thereof we must speak.
\end{abstract}

Key words: new media; true; false; pandemic; fake news.

Triviális, hogy az új médiában - leegyszerüsítve a neten - úgyszólván bármirőlbárkiről megtalálható az igaz ismeret, hasonlóképpen a hamis vagy éppen a meghamisított is. Némi erőfeszítéssel, szorgos kattintásokkal, legrosszabb esetben előfizetési díj ellenében hozzáférhetünk bármely tudományos kutatás eredményéhez, az azokat cáfolókhoz is, s nem kell a „,szolgálatokhoz” tartozni ahhoz, hogy beleláthassunk a titkos vagy annak szánt politikai ténykedések némelyikébe. Már csak azért sem, mert egy széles értelemben vett „cselszövés” elöbb-utóbb a nem-titkos szférában is megjelenik, különben nem volna értelme.

Ami a ,net” egészére igaz, az a Facebookra is áll. 
A Facebook a köznapi világ része (vö. bővebben Kállai R. 2020, 29-34.), s olyannyira kiterjedt, hogy némi erőfeszítéssel megtalálható rajta minden olyan ismeret, ami segít eligazodni a világban, a politikában, de még a tudományokban is, és persze ennek az ellenkezője is, azaz a szokásos felhasználó rendelkezésére állnak az igaz ismeretek s a hamisak egyaránt. Ez természetesen a közelmúlt és a jelen nagy, globális problémájára, a pandémiára is vonatkozik.

A pandémia - a statisztikák és sajnos saját élettapasztalatunk alapján is kijelenthetö - behatolt a mindennapjainkba, a köznapi élet részévé vált. Akár úgy, hogy mi magunk vagy ismerőseink, barátaink, rokonaink betegszenek meg, egyesek talán meg is halnak, de úgy is, hogy vakcinát kell beadatni, maszkban kell szuszogni, webkamerára meredve előadást tartani és vizsgáztatni, monitoron színházat nézni, esetleg lemaradni fontos és érdekes nemzetközi konferenciáról.

A Facebookon az elmúlt másfél-két évben jócskán megnőtt azok száma, akik kifejezetten a pandémia általános okairól, lefolyásáról, perspektíváiról beszéltek, posztoltak, chateltek. Ezt az amúgy nyilvánvaló felismerést számos szociológiai, szociálpszichológiai elemzés, statisztika, tartalomelemzés és más kutatás is alátámasztja. Néhány kattintás azt az előfeltevést is megerősítheti, hogy a véleménybuborékok léte ebben a témakörben is adottnak vehető. Számos felhasználó olyan bejegyzéseket keres fel, amelyek kutatásokat ismertetnek, esetleg személyes tapasztalatokról számolnak be, mások viszont előszeretettel lépnek be különféle járványtagadó, oltásellenes, csoportokba, átvesznek, netán kitalálnak különféle „konteókat”, sokan áltudományos videókat, posztokat osztanak meg. Ezek típusai is ismertek, tanulmányok írása és feldolgozása helyett olykor elegendő belefeledkezni néhány erre szakosodott csoport bejegyzéseinek és videóinak szemlélésébe. Javaslom például „A koronavírus pánikot csökkentő csoport - Tamási doktor csoportja” megtekintését, amelynek jelenleg 34000 tagja van.

Ahhoz sem kell mélyebb elemzés, hogy a járványtagadó csoportok tagjai roppant eltérő társadalmi státuszúak, magasan kvalifikált emberek, orvosok, szakemberek éppúgy akadnak közöttük, mint helyesírási nehézséggel küszködő egyszerü polgárok. Olykor megjelennek politikusok is mint véleményvezérek, gondoljunk például Jair Bolsonaro brazil elnökre, aki ellen - egyebek mellett - a járvány lebecsülése, hamis információk terjesztése, a vakcinák beszerzésének akadályozása s az ez okból bekövetkezett 600000 -nél is több haláleset miatt emberiesség elleni bủnök vádjával kívánnak eljárást indítani (Anon. 2021).

Azt hinnénk - egészen addig, amíg be nem kapcsolódunk a köznapi vitákba az oltások és a járvány kapcsán -, hogy a tudományra, jelen esetben az orvostudomány megfelelő ágazataira, a statisztikai tényekre, mérésekre, szakcikkekre való hivatkozás talán meggyőzheti vitapartnereinket a járvány valóságáról. Ennek azonban több ismeretelméleti akadálya van - persze nem számítva az emberi értetlenséget és gyarlóságot. 
Az első az, hogy mind a pandémia, mind az azt okozó vírus bizonyos értelemben jelen idejü, tehát a tudománynak - maradjunk a leegyszerüsített általános megnevezésnél - egyszerüen nem volt ideje a megismerésére. A tudomány ugyanis ha úgy tetszik - mindig múlt idejü. Ez mellesleg az egyéni tapasztalatra is áll. Hegellel szólva:

Azt, amit a fogalom tanít, szükségszerüen éppúgy mutatja a történelem is, hogy csak ha megérett a valóság, jelenik meg az ideális a reálissal szemben, s hogy az ideális ugyanazt a világot, szubsztanciájában megragadva, építi fel magának egy értelmi birodalom alakjában. Ha a filozófia szürkét szürkébe fest, akkor az élet egy alakja megöregedett, s szürkével szürkébe meg nem fiatalítható, hanem csak megismerhető. Minerva baglya csak a beálló alkonnyal kezdi meg röptét.

Hegel 1971, 23

A már meglévő ismeretek persze adnak esélyt egyfajta előrelátásra, tendenciák, alternatívák felismerésére, a jóslás sem feltétlenül kizárt, főleg, ha olyan trendekre vonatkoznak, amelyek kialakítása, folytatása emberi cselekvésen, teleológiai tételezéseken múlik. „A filozófusok a világot csak különbözőképpen értelmezték; a feladat az, hogy megváltoztassuk." (Marx 1960b, 8.)

A Hegeltől és Marxtól vett idézetek ugyan a filozófiáról szólnak, de álláspontjuk kiterjeszthető akár a természettudományokra is, persze ahogy mondani szokás, mutatis mutandis.

A pandémia kapcsán nemegyszer felvetődik a vitákban a tudomány célja is, ami az adott esetben nyilvánvalóan a járvány leküzdését jelenti, sok áldozattal, nehézséggel, bezártsággal, bajjal járva, rövidebb-hosszabb idő múlva viszont talán el is felejthetjük ezeket az éveket. (Persze ez nem volna racionális magatartás.) De általánosabban is

[...] a tudomány végső célja az volna, hogy az embernek lehetőleg sok örömöt $\mathrm{s}$ lehetőleg kevés fájdalmat szerezzen! De hátha az élvezet és fájdalom úgy össze van bogozva, hogy aki a lehető legtöbbet akar az egyikből, kénytelen a lehető legtöbbet vállalni a másikból is - hogy aki »égig« akar »ujjongani«, legyen kész a »halálos szomorúság « állapotára is? S lehet, hogy ez csakugyan így is van!

Nietzsche 1926, 32

A tudomány feladata - brutálisan leegyszerüsítve - a valóság adekvát megismerése, visszatükrözése. „Mit jelent megismerni? - »Se nevetni, se sírni, sem elvetni, hanem megismerni!« - mondja Spinoza a maga szokásos egyszerü és fenséges módján. De végső elemzésben mi más ez az »intelligere«, mint az a forma, amely velünk egyszerre érezteti ama háromságot?

Nietzsche 1926, 227

Azaz a tudomány müvelése korántsem egyszerü, érzelemmentes dolog. Nietzsche ugyan nem említi, de a szellemieken kívül kell hozzá pénz, müszer, pályázati támogatás, 
politikai „hátszél”, társadalmi elfogadottság - hogy csak néhány dolgot emeljek ki. A tudós, a tudomány embere $-\mathrm{s}$ a mindennapi okoskodó is - bizonyos összefüggéseket adottnak tekinthet, ebben azonban nem csak a tudás jelenik meg, hanem egyfajta hit is bizonyos nyilvánvaló tényekben:

Én, L. W., hiszem, biztos vagyok benne, hogy a barátomnak nem fürészpor van a testében vagy a fejében, bár nincs erről közvetlen érzéki evidenciám. Annak alapján vagyok ebben biztos, amit nekem mondottak, amit olvastam, és amiket megtapasztaltam. Kételkedni ebben örültségnek tünik számomra, természetesen szintén a többiekkel egyetértésben, de én értek velük egyet.

Wittgenstein 1989, 76

Az ismeret és a tárgyi világ, azaz amiről ismereteket akarunk szerezni, több okból, köztük éppen a felhalmozott tudás miatt bizonyos értelemben elválik egymástól. Az elmúlt századelőn is felvetődött a probléma - gondoljunk a fizika forradalmára -, és persze ma is „kérdésessé válik az ismeret lehetősége [...], hogy képes-e a megismerés »eltalálni« az objektivitást, azt, ami mégiscsak az, ami." Vagy kissé később: „Kérdésessé vált az olyan tárgyiság értelme, amelyik van, és az, ami, attól függetlenül, hogy megismerik-e vagy sem." (Husserl 1972, 52-53.)

A pandémia létéről, állapotáról, esetleg perspektíváiról természetesen nem csak a „Tudománytól” kaphatunk ismereteket, sok és fontos információval lát el a statisztika feltéve, ha időben és korrektül közzéteszik -, háziorvosunk, föleg, ha bejutunk hozzá, de akár a „civilben” temetkezési vállalkozó levelező egyetemi hallgató az online tanórán. S persze a Facebook. Így vagy úgy, ha ragaszkodunk a világ s benne a pandémia megismeréséhez, és nem vagyunk szakemberek, vágyunk egyfajta bensőségességre, párbeszédre, amelyet nagyon nehéz megtalálni.

De az otthonosság feltétele az ember számára az abszolút beláthatóság, belátottsága és megértése életünknek és tényei összefüggésének. Ehhez elöször is ismernünk kell e tényeket, egzakt és határozott leírásai fölött kell rendelkeznünk. Mily nagy erőfeszítés kell azonban ahhoz, hogy az emberi élet magát megértse, gondolkozását, beszédjét, vágyait, kívánságait, s mily sok az, amit meg kell értenie. S ha mind a sokat megértette, még mindig csak egyes tényeket értett meg, nem az Egészet, az élet és az emberi magatartás egész voltát.

Szilasi 1930

Az otthonosság, a beláthatóság azonban - mint minden - a köznapi megismerésben egyfajta rossz reduktivitáshoz vezethet, vezet is. Az elénk tolakodó számtalan jelenséget, folyamatot szokás ugyanis visszavezetni a vélt vagy valós lényegükre, néhányat fentebb már megemlítettem. Nagyon könnyű eljutni egyfajta eidetikus redukciót alkalmazva a nyelvileg különböző formában megjelenő „valami” tételezéséhez. „Valami okozza a járványt”, „valami” oka van az oltás bevezetésének, „valami” akadályozza a normális életet - stb. A „,valami” olyan szubjektum, amihez 
számtalan predikátum rendelhető, lehet szándék, cél, indulat, egyszóval bármi, ami meghatározottsággal bír, csak éppen a meghatározottsága bizonytalan. A ,valami” emellett egyéni, az énáltalam meghatározott „valami” nem azonos az őáltala összehozott „,valamivel” - bár még az is előfordulhat (bővebben: Kállai R. 2016).

A ,valami” tehát meghatározottságától függően egyszerü könnyebbséget is jelenthet a mindennapi megismerésben, hiszen - ha nem vagyunk ,profik” abban a dologban, amivel véletlenül összeakadunk - bőven elég annyit tudni, hogy „,valami” miatt kell, „valami” miatt ilyen stb. Ha például meglátunk egy maszkviselésre felszólító feliratot, táblát, nem kell tudnunk a vírus terjedésének pontos módjáról, nem kell ismerni a tábla méretét, nem kell felsorolni magunkban a kifüggesztésére vonatkozó jogszabályokat csak fel kell venni a maszkot.

A baj ott kezdődik, pontosabban ott van, ha a privát „valami”, amit tehát maga gyárt az alany, félrevezető, netán magára vagy másra, másokra káros.

Egy derék férfiú egyszer azt vette a fejébe, hogy az emberek csak azért fulladnak bele a vízbe, mert a nehézkedés gondolata megszállva tartja őket. Ha ezt a képzetet kivernék a fejükből, teszem úgy, hogy azt babonás, vallási képzetnek nyilvánítanák, akkor mindenféle vízveszélyen felülkerekednének. Egész életén át küzdött a nehézkedés illúziója ellen, amelynek káros következményeiről neki minden statisztika új és számos bizonyítékot szolgáltatott. Ez a derék férfiú volt a mintaképe az új német forradalmi filozófusoknak."

Marx 1960a, 18

Nem tudni, hogy a példázatban említett derék férfiú próbára tette-e a gravitáció létezését akár csak egy székre felállva is - elsősorban példájával hatott a bölcseletre. A pandémiát hasonló módon tagadók - s vannak szép számmal - viszont a szó szoros értelmében ön- és közveszélyesek. Ezért aztán hiába támad menekülhetnékünk ilyen vitapartnerrel találkozva - ha személyesen, akkor betartva a szociális távolságot, ha a Facebookon, akkor szorgosan „csettegve” -, vállalni kell a dialógust. Másokért, és persze magunkért is.

\section{KÖNYVÉSZET}

Anon., 2021, Em silêncio, Brasil chora 600 mil sonhos despedaçados pela Covid [online]. [Letöltés időpontja: 2021.11.21.] Elérhető: https://pt.org.br/em-silenciobrasil-chora-600-mil-sonhos-despedacados-pela-covid/

HEGEL, Georg Wilhelm Friedrich, 1971, Jogfilozófia, Budapest, Akadémiai.

HUSSERL, Edmund, 1972, A fenomenológia ideája - Öt előadás. In Edmund Husserl válogatott tanulmányai, Budapest, Gondolat.

KÁLLAI R. Gábor, 2016, Franz Kafka rejtőzködő filozófiája, Budapest, Typotop.

KÁLLAI R. Gábor, 2020, A Facebook mint köznapiság, Symbolon, No. 36, 29-34.

MARX, Karl, 1960a, A német ideológia. In Marx-Engels müvei 3., Budapest, Kossuth. 
MARX, Karl, 1960b, Tézisek Feuerbachról. In Marx-Engels müvei 3., Budapest, Kossuth.

NIETZSCHE, Friedrich, 1926, Vidám tudomány, Budapest, Világirodalom Könyvkiadó Vállalat.

SZILASI Vilmos, 1930, Edmund Husserl, Nyugat, 1930., No. 7.

WITTGENSTEIN, Ludwig, 1989, A bizonyosságról, Budapest, Európa. 